\title{
JAN JACOB HARTSINCK
}

DOOR

FRED. OUDSCHANS DENTZ

Mr. Jan Jacob Hartsinck werd 14 October 1716 te Amsterdam geboren, waar hij den 28sten October 1779 overleed. Hij was de zoon van Jan Caspar en Johanna Cornelia Pels. Op zijn 8ste jaar werd hij klerk ter secretarie van het college ter admiraliteit van Amsterdam, in 1743 heemraad van Watergraafsmeer, in 1762 charter- en requestmeester van de admiraliteit, president van de hoofdparticipanten der West-Indische compagnie en lid van het Zeeuwsch genootschap der wetenschappen te Vlissingen. Hij werd in 1774 directeur van de Hollandsche maatschappij der wetenschappen te Haarlem, lid van de commissie van regenten van het oudemannenhuis te Amsterdam en tevens van de schouwburg aldaar.

Hartsinck was eerst gehuwd met Geertruida Constantia Sweedenrijck, die evenals hij vele dichterlijke gaven bezat en den 23 sten Februari 1742 overleed. Daarna trad hij in het huwelijk met Anna Adriana Hasselaar.

In zijn betrekking tot de West-Indische compagnie - zijn vader was gedurende 23 jaren directeur van de Societeit van Suriname - verzamelde hij de bouwstoffen voor de samenstelling van zijn klassiek werk: Beschrijving van Guiana, of de Wilde Kust in Zuid-America, zooals het kortelijks wordt aangehaald, maar waar van de rest van de wijdloopige titel luidt: Betreffende de Aardrijkskunde en Historie des Lands, de Zeeden en Gewoontes der Inwooners, de Dieren, Vogels, Visschen, Boomen en Gewassen, als mede de eerste Ontdekking dier Kust, de Bezittingen der Spanjaarden, Franschen en Portugeezen en voornaamelijk de Volkplantingen der Nederlanderen, als Essequebo, Demerary, Berbice, Suriname, En derzelver Rivieren, met de noodige Kaarten en Afbeeldingen der Forten. Waarbij komt eene Verhandeling over den Aart en de Gewoontes der Neger-Slaaven". 
Het werk verscheen in 1770 te Amsterdam bij Gerrit Tielenburg in twee deelen met doorloopende pagineering en was opgedragen aan Willem den vijfden, prins van Oranje en Nassau, erf-stadhouder, capitein en admiraal generaal, benevens opperbewindhebber der Oost- en West-Indische maatschappijen der Vereenigde Nederlanden enz. enz. enz.

In het eerste deel behandelt Hartsinck de kolonies Poumeron, Essequebo, Demerary en Berbice van blz. 257 tot 521. In deel II behandelt hij Suriname van blz. 521 tot 898, waarna van blz. 898 tot blz. 922 een beschrijving der slaven volgt en een Bijvoegsel, van blz. 923 tot 962, dat behoort bij het gedeelte van deel I: Ontdekkingen en Bezittingen der Nederlanders, voorkomende op blz. 206 (Hartsinck verwijst bij vergissing naar blz. 111). De beide deelen bevatten 5 kaarten en 10 afbeeldingen. Voorts vindt men in deel I een naamlijst van ,directeuren van de Geoctoyeerde Colonie de Berbice beginnende met den Jaare 1720" en een naamlijst van gouverneurs van die kolonie. In deel II komt voor de giftbrief van 2 Juni 1650 van Karel II aan lord Willoughby in het Engelsch en het Nederlandsch, het Octrooi van 23 September 1682 , de condities van den verkoop van de kolonie Suriname door de West-Indische Compagnie aan de stad Amsterdam en Cornelis van Aerssen van Sommelsdyck, een naamlijst van de directeuren van de Sociteit van Suriname van 1683 tot 1769, een naamlijst van gouverneurs, commandeurs, raden-fiscaal en secretarissen van Suriname.

Hartsinck was een zeer kundig man met een helder verstand. Ook als letterkundige en blijspeldichter maakte hij naam. Zijn gedichten werden niet uitgegeven. $\mathrm{Zij}$ waren geestig en luimig. Van de vier tooneelstukken, welke hij schreef, werden er drie in het Fransch vertaald. Het vierde werd na zijn overlijden in 1780 opgevoerd. 